\title{
Three-dimensional visualisation of developmental stages of an apicomplexan fish blood parasite in its invertebrate host
}

\author{
Polly M Hayes ${ }^{1,3^{*}}$, David F Wertheim², Nico J Smit ${ }^{4}$, Alan M Seddon ${ }^{1}$ and Angela J Davies ${ }^{1}$
}

\begin{abstract}
Background: Although widely used in medicine, the application of three-dimensional (3D) imaging to parasitology appears limited to date. In this study, developmental stages of a marine fish haemogregarine, Haemogregarina curvata (Apicomplexa: Adeleorina), were investigated in their leech vector, Zeylanicobdella arugamensis; this involved 3D visualisation of brightfield and confocal microscopy images of histological sections through infected leech salivary gland cells.

Findings: 3D assessment demonstrated the morphology of the haemogregarine stages, their spatial layout, and their relationship with enlarged host cells showing reduced cellular content. Haemogregarine meronts, located marginally within leech salivary gland cells, had small tail-like connections to the host cell limiting membrane; this parasite-host cell interface was not visible in two-dimensional (2D) light micrographs and no records of a similar connection in apicomplexan development have been traced.

Conclusions: This is likely the first account of the use of 3D visualisation to study developmental stages of an apicomplexan parasite in its invertebrate vector. Elucidation of the extent of development of the haemogregarine within the leech salivary cells, together with the unusual connections between meronts and the host cell membrane, illustrates the future potential of 3D visualisation in parasite-vector biology.
\end{abstract}

\section{Findings}

Haemogregarines are elongate, protistan parasites found in the blood cells of a number of vertebrate hosts, especially marine fishes [1-4]. Fish haemogregarine life cycles are largely unknown, although some are suspected to involve leech vectors [5-11], while others may utilize crustacean isopods as invertebrate hosts [4,12-14]. Recently, Hayes et al. [11] described developmental stages of the marine fish haemogregarine Haemogregarina (sensu lato) curvata Hayes, Smit, Seddon, Wertheim and Davies, 2006 (Apicomplexa: Adeleorina) from the bluntnose klipfish Clinus cottoides (Valenciennes, 1836) and the rhyncobdellid leech Zeylanicobdella arugamensis De Silva, 1963. The life cycle for $H$. curvata is shown in Figure 1, including sporozoite, merozoite and meront stages imaged in the current study (Figure 1O-R).

\footnotetext{
* Correspondence: p.hayes@kingston.ac.uk

${ }^{1}$ School of Life Sciences, Faculty of Science, Engineering and Computing,

Kingston University, Kingston upon Thames, Surrey KT1 2EE, UK

Full list of author information is available at the end of the article
}

This apicomplexan was only the third valid species of marine fish haemogregarine to have been named from South Africa [11,12,15-18], and the only species from this region for which developmental stages within a leech vector have been described [11]. Stages of $H$. curvata observed by Hayes et al. [11] in squash preparations of $Z$. arugamensis included gamonts, oocysts, sporozoites and merozoites. In histological sections of the same leech sporozoites and merozoites were located in tissue adjacent to and within the dorsal sinus, while sporozoites, meronts and merozoites were found in leech salivary gland cells close to the proboscis [11].

Subsequent to the published description of H. curvata, it became possible to examine the developmental stages of this parasite further. This was achieved using histological sections of infected leech salivary glands and by investigating the parasite-host cell relationship by threedimensional (3D) visualisation, linked to brightfield or confocal microscopy. This revealed new insights into the
Ciomed Central

(c) 2011 Hayes et al; licensee BioMed Central Ltd. This is an Open Access article distributed under the terms of the Creative Commons Attribution License (http://creativecommons.org/licenses/by/2.0), which permits unrestricted use, distribution, and reproduction in any medium, provided the original work is properly cited. 


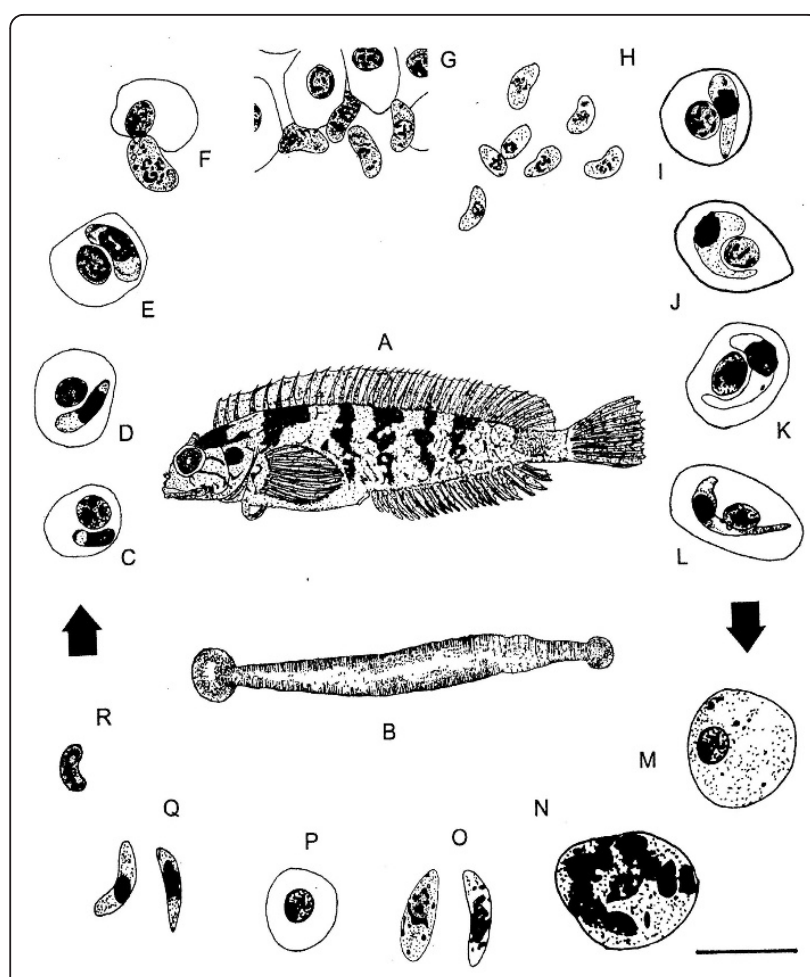

Figure 1 A-R. Life cycle of Haemogregarina curvata. A: Clinus cottoides redrawn from Penrith [26] (not drawn to scale). B: Adult Zeylanicobdella arugamensis redrawn from De Silva [27] (not drawn to scale). C-R: Microscope drawings to illustrate the life cycle of Haemogregarina curvata. C-L: Stages within peripheral blood smears from C. cottoides. M-R: Stages within Zeylanicobdella arugamensis squashes and histological sections through salivary glands. Arrows indicate stages of suspected transfer of haemogregarine from one host to another. C: Small intraerythrocytic trophozoite. D: Larger trophozoite. E: Intraerythrocytic meront. F: Extracellular meront. G, H: Extracellular merozoites. I: Intraerythrocytic pregamont form. J: Immature gamont. K Intermediate gamont. L: Mature

intraerythrocytic gamont. M Immature oocyst. N Developing oocyst with 8-10 nuclei. O: Free sporozoites. P: Meront. Q: First generation merozoites. $\mathbf{R}$ : Second generation merozoite. Scale bar $=10 \mu \mathrm{m}$.

development and parasite-host cell interactions of the apicomplexan within its leech vector (Figure $2 \mathrm{~A}-\mathrm{H}$ ).

$3 \mathrm{D}$ images of the stages of $H$. curvata within the salivary gland cells of $Z$. arugamensis were achieved by the visualisation and modelling software Amira 4.0 (Mercury Group Systems, USA). This system was used to create $3 \mathrm{D}$ visualisations of two-dimensional (2D) digital brightfield microscopy images (a stacked series of histological sections) and confocal microscopy images (a stacked series of scans through individual histological sections). Images of haematoxylin and eosin stained histological sections were captured as detailed by Hayes et al. [11]. Prior to 3D visualisation, brightfield images were aligned, manually if necessary, using the Amira software. As confocal images were a series of scans through single histological sections (typically, z stacks of 10-26 slices), additional alignment was not necessary.

In Amira 4.0, following alignment of brightfield microscopy images, the brightness and contrast were adjusted, and a median filter $(5 \times 5 \mathrm{kernel})$ was applied to reduce noise before further brightness and contrast adjustments were made. The images were then stacked and displayed as $3 \mathrm{D}$ visualisations of individual orthoslices, or using a $3 \mathrm{D}$ volume rendering (voltex) module which displayed the images as a texturised $3 \mathrm{D}$ visualisation. Confocal images applied directly to the 3D imaging software, were also viewed as either individual orthoslices, or using the voltex module (both green and red channels were displayed showing autofluorescence from the sample sections using the argon (488 $\mathrm{nm}$ excitation) and helium/neon (453 nm excitation) lasers, and XYZ coordinates set, as appropriate).

Stacked brightfield images of histological sections $(\mathrm{n}=$ $10)$ through the anterior portion of $Z$. arugamensis displayed either as individual orthoslices or as volume rendered (voltex) visualisations, provided a good overview of this region of the internal anatomy of the leech, including the position, form and spatial layout of the salivary glands and proboscis (Figure 2A). Recently, Davies et al. [4] reported using similar methods to investigate the internal anatomy of juvenile gnathiid isopods and the potential use of the techniques in locating the development sites of another fish haemogregarine, Haemogregarina bigemina Laveran and Mesnil, 1901 [4,12,13,15-17].

$3 \mathrm{D}$ visualisations of confocal images of the salivary gland cells of $Z$. arugamensis infected with $H$. curvata were superior to stacked brightfield images of this region in quality, providing an appreciation of the morphology and arrangement of the developmental stages of the haemogregarine, and their relationship with the host cells (Figure 2B-H). Furthermore, volume rendered (voltex) $3 \mathrm{D}$ images (Figure 2E-H), in contrast to those displayed as individual orthoslices (Figure 2D), appeared to provide the clearer delineation of structure.

Stacked orthoslice and voltex visualisations of 10 confocal images through single histological sections of salivary gland cells showed merozoites, sporozoites and meronts in some detail. These stages lay freely within enlarged salivary gland cells as individuals, or in small clusters, especially marginally, adjacent to the salivary cell limiting membrane (Figure 2E-H). Voltex displays, in particular, showed the surface morphology of individual stages and their spatial layout (Figure 2E-H). These images also illustrated the reduced cellular contents of infected host cells reported by Hayes et al. [11] with host cell content remnants visible among the haemogregarine stages (Figure 2E-H); this suggests a pathological effect of $H$. curvata infection on its invertebrate host, as 

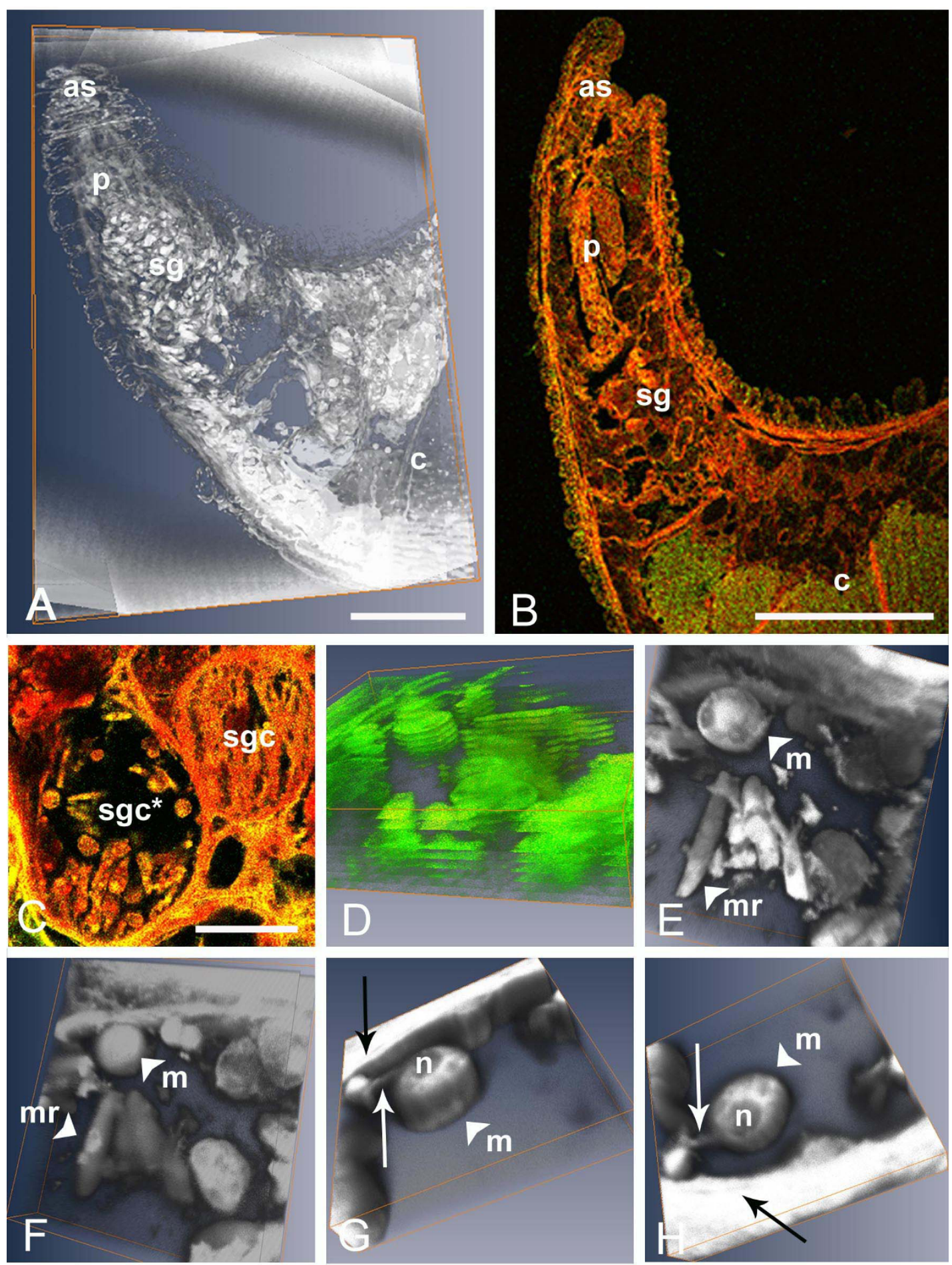

Figure $2 \mathrm{~A}-\mathrm{H}$. Three-dimensional (3D) visualisations (A, D-H) and confocal images (B, C; green and red channel overlays) of the leech Zeylanicobdella arugamensis and developmental stages of Haemogregarina curvata within its salivary gland cells. A: Voltex 3D

visualisation of bright field microscopy images of stacked haematoxylin and eosin (H\&E) stained histological sections ( $\mathrm{n}=10)$, and $\mathbf{B}$ : a confocal image of a single H\&E stained section, through the anterior end of $Z$. arugamensis, showing anterior sucker (as), proboscis ( $p$ ), salivary glands (sg) and crop (c). Scale bars: A and B, 0.2 mm, Z axis in A not to scale. C: Non-infected (sgc) and infected (sgc) leech salivary gland cells. Scale bar = $20 \mu \mathrm{m}$. D - F: Stacked orthoslice (D) and voltex (E-H) 3D visualisations of 10 stacked confocal images of infected salivary gland cells, showing haemogregarine stages at various angles of rotation (green and red channels displayed), with meront $(\mathrm{m})$ and merozoite $(\mathrm{mr})$ stages. G-H: 3D visualisation of 26 stacked confocal images of a marginally located meront $(\mathrm{m})$ with prominent nucleus $(\mathrm{n})$ and a tail-like connection (large arrows) to the salivary gland cell limiting membranes at different rotations. $X-Y-Z$ axis dimensions for visualisations $=30 \mu \mathrm{m} \times 30 \mu \mathrm{m} \times 6 \mu \mathrm{m}(\mathrm{D}$ F), $17 \mu \mathrm{m} \times 17 \mu \mathrm{m} \times 3 \mu \mathrm{m}(\mathrm{G}-\mathrm{H})$. 
indicated by Hayes et al. [11]. When examined closely using voltex displays of 10-26 confocal images, the majority of meronts located marginally within salivary gland cells were seen with small tail-like connections to the host cell limiting membrane (Figure 2G-H). This host cell-parasite interface had not been visible in $2 \mathrm{D}$ light micrographs [11]. The purpose of this tail-like structure is not clear; it may be essential for the continued growth and development of the meront stage within the salivary cell, acting as a conduit for nutritional needs, or perhaps it is a remnant of earlier development (of sporozoites or a previous generation of merozoites) within the host cell. Uni et al. [19] observed, by transmission electron microscopy, a connection between the coccidian Cryptosporidium muris (Strain RN66) and mouse gut mucus cells in the form of an annular ring; this structure was interpreted as having a role in anchoring the parasite to the inner region of the host cell.

Despite being used widely in medicine, for example, in displaying Magnetic Resonance Images [20-22], the use of $3 \mathrm{D}$ visualisation in parasitology, particularly using brightfield and confocal images, appears limited to date [see [23]]. Shinn et al. [24] used 3D reconstruction of scanning electron micrographs to observe structural details of the marginal hooks of monogenean parasites of fishes, while Ligasová et al. [25] produced a 3D model of secretory glands in cercaria of the neuropathogenic schistosome Trichobilharzia regenti using confocal microscopy. To the authors' knowledge this is the first account of the use of $3 \mathrm{D}$ visualisation to examine the developmental stages of an apicomplexan parasite in its invertebrate host. The ability to reveal the extent of development of the haemogregarine within leech salivary cells, together with the unusual connections between meronts and the host cell membrane, illustrates the future potential of this technique in this field.

\section{Acknowledgements}

This work was supported by a study abroad grant from The Royal Society for AJD, and funding from The Claude Harris Leon Foundation for NJS.

\section{Author details \\ ${ }^{1}$ School of Life Sciences, Faculty of Science, Engineering and Computing, Kingston University, Kingston upon Thames, Surrey KT1 2EE, UK. ${ }^{2} \mathrm{Sch}$ col of Computing and Information Systems, Faculty of Science, Engineering and Computing, Kingston University, Kingston upon Thames, Surrey KT1 2EE, UK. ${ }^{3}$ Department of Zoology, The Natural History Museum, London SW 7 5BD, UK. ${ }^{4}$ School of Environmental Sciences and Development, North West University, Potchefstroom, South Africa.}

\section{Authors' contributions}

PMH conceived the project, carried out the experimental work, participated in the data analysis and wrote the manuscript. DFW conceived the project, participated in the data analysis and provided significant support to the preparation of the manuscript. NJS organised sample collection and, with AMS, participated in drafting the manuscript. AJD conceived the project and provided significant support to the preparation of the manuscript. All authors read and approved the final manuscript.

\section{Competing interests}

The authors declare that they have no competing interests.

Received: 29 July 2011 Accepted: 22 November 2011

Published: 22 November 2011

\section{References}

1. Davies AJ: The biology of fish haemogregarines. Adv Parasitol 1995, 36:117-203.

2. Davies AJ, Johnston MRL: Biology of some intraerythrocytic parasites of fishes, amphibians and reptiles. Adv Parasitol 2000, 45:1-105.

3. Davies AJ, Merrett NR: Haemogregarines and other blood infections from deep demersal fish of the Porcupine Seabight, north-east Atlantic. J Mar Biol Assoc UK 2000, 80:1095-1102.

4. Davies AJ, Smit NJ, Hayes PM, Seddon AM, Wertheim DF: Haemogregarina bigemina (Protozoa: Apicomplexa: Adeleorina) - past, present and future. Folia Parasitol 2004, 51:99-108.

5. So BFK: Marine fish haematozoa from Newfoundland waters. Can J Zool 1972, 50:543-554.

6. Khan RA, Barrett M, Murphy J: Blood parasites of fish from the northwestern Atlantic Ocean. Can J Zool 1980, 58:770-781.

7. Siddall ME, Desser SS: Ultrastructure of merogonic development of Haemogregarina (sensu lato) myoxocephali (Apicomplexa: Adeleina) in the marine leech Malmania scorpii and localization of the infective stages in the salivary cells. Eur J Protistol 1993, 29:191-201.

8. Siddall ME, Burresson EM: The development of a haemogregarine of Lycodes raridens from Alaska in its definitive leech host. J Parasitol 1994, 80:569-575.

9. Siddall ME, Desser SS: Developmental stages of Haemogregarina delagei in the leech Oxytonostoma typica. Can J Zool 2001, 79:1897-1900.

10. Siddall ME: Phylogeny of adeleid blood parasites with a partial systematic revision of the haemogregarine complex. I Eukaryot Microbiol 1995, 42:116-125.

11. Hayes PM, Smit NJ, Seddon AM, Wertheim DF, Davies AJ: A new fish haemogregarine and its suspected dual transmission with trypanosomes by a marine leech. Folia Parasitol 2006, 53:241-248.

12. Davies AJ, Smit NJ: The life cycle of Haemogregarina bigemina (Adeleina: Haemogregarinidae) in South African hosts. Folia Parasitol 2001, 48:169-177.

13. McKiernan JP, Grutter AS, Davies AJ: Reproductive and feeding ecology of parasitic gnathiid isopods of epaulette sharks (Hemiscyllium ocellatum) with consideration of their role in the transmission of a haemogregarine. Int J Parasitol 2005, 35(1):19-27.

14. Smit NJ, Grutter AS, Adlard RD, Davies AJ: Hematozoa of teleosts from Lizard Island, Australia with some comments on their possible mode of transmission and the description of a new haemogregarine species. J Parasitol 2006, 92:778-788.

15. Smit NJ, Davies AJ: New host records for Haemogregarina bigemina from the coast of southern Africa. J Mar Biol Assoc UK 1999, 79:933-935.

16. Smit NJ, Davies AJ: An encapsulated haemogregarine from the evileye pufferfish in South Africa. J Mar Biol Assoc UK 2001, 81:751-754.

17. Smit NJ, Van As JG, Davies AJ: Taxonomic re-evaluation of the South African fish haemogregarine Desseria fragilis. J Parasitol 2003, 89:151-153.

18. Smit NJ, Davies AJ: Intraerythrocytic merogony in Haemogregarina koppiensis (Apicomplexa: Adeleorina: Haemogregarinidae). Folia Parasitol 2005, 52:277-278.

19. Uni S, Iseki M, Maekawa T, Moriya K: Ultrastructure of Cryptosporidium muris (strain RN 66) parasitizing the murine stomach. Parasitol Res 1987, 74:123-132.

20. Hellinger JC, Medina LS, Epelman M: Pediatric advanced imaging and informatics: state of the art. Semin Ultrasound CT MR 2010, 31(2):171-93.

21. Tongdee R, Naraa VR, Oliveira EP, Chapman W, Elsayes KM, Brown JJ: Utility of $3 \mathrm{D}$ magnetic resonance imaging in preoperative evaluation of hepatobiliary diseases. HPB (Oxford) 2006, 8(4):311-317.

22. Kavanagh EC, Read P, Carty F, Zoga AC, Parvizi J, Morrison WB: Threedimensional magnetic resonance imaging analysis of hip morphology in the assessment of femoral acetabular impingement. Clin Radiol 2011, 66(8):742-7.

23. Galli IP, Strona G, Villa AM, Benzoni F, Stefani F, Doglia SM, Kritsky DC: Twodimensional versus three-dimensional morphometry of monogenoidean sclerites. Int J Parasitol 2007, 37:449-456. 
24. Shinn A, Bron AE, Sommerville C, Gibson DI: Comments on the mechanism of attachment in species of the monogenean genus Gyrodactylus. Invert Biol 2000, 122:1-11.

25. Ligasová A, Butanová J, Šebesta O, Kašný M, Koberna K, Mikeš L: Secretory glands in cercaria of the neuropathogenic schistosome Trichobilharzia regenti - ultrastructural characterization, 3-D modeling, volume and $\mathrm{pH}$ estimations. Parasites and Vectors 2011, 4:162

26. Penrith M: The systematics of the fishes in of the family Clinidae in South Africa. Annls S Afr Mus 1969, 55:1-121.

27. De Silva PHDH: Zeylanicobdella arugamensis gen. nov. and sp. Nov. from Arugam Kalapu, Eastern Province, Ceylon. Spolia zeylan 1963, 30:46-53.

doi:10.1186/1756-3305-4-219

Cite this article as: Hayes et al:: Three-dimensional visualisation of developmental stages of an apicomplexan fish blood parasite in its invertebrate host. Parasites \& Vectors 2011 4:219.

\section{Submit your next manuscript to BioMed Central} and take full advantage of:

- Convenient online submission

- Thorough peer review

- No space constraints or color figure charges

- Immediate publication on acceptance

- Inclusion in PubMed, CAS, Scopus and Google Scholar

- Research which is freely available for redistribution

Submit your manuscript at www.biomedcentral.com/submit 